Захарчук Віктор Миколайович кандидат юридичних наук, доцент, доцент кафедри кримінального права та процесу Хмельницького університету управління та права імені Леоніда Юзькова, м. Хмельницький, 29000,вул. Героїв Майдану, 8, тел.: (097) 74-539-54, e-mail: yur_viddil@univer.km.ua, https://orcid.org/0000-00020896-3747

\title{
МАЙНОВА ШКОДА В СИСТЕМІ КРИМІНАЛЬНО-ПРОТИПРАВНИХ НАСЛІДКІВ
}

Анотація. У статті здійснено наукове дослідження майнової шкоди як одного із видів кримінально-протиправних наслідків. Систематизовано кримінальні правопорушення, обов'язковою ознакою об'єктивної сторони яких є наслідки у виді майнової шкоди або загрози настання такої шкоди. Встановлено, що досить часто саме наявність майнової шкоди у певному розмірі зумовлює визнання того чи іншого діяння кримінальним правопорушенням певного виду або слугує для диференціації кримінальної відповідності шляхом виділення кваліфікованих та особливо кваліфікованих складів кримінальних правопорушень. При цьому майнова шкода визначається в кожному конкретному випадку виходячи з оцінки усіх обставин справи.

Досліджено, що при визначенні виду та розміру майнової шкоди як кримінально-протиправного наслідку в першу чергу потрібно використовувати цивільно-правове розуміння даного поняття. Встановлено, що в теорії кримінального права існують два кардинально різні підходи щодо включення до складу майнової шкоди упущеної вигоди, яка не $є$ прямим матеріальним збитком. Проаналізовано механізм заподіяння майнової шкоди об’єкту кримінальноправової охорони. Переважно він полягає у розриві суспільних відносин щодо правомочностей власника володіти, користуватися і розпоряджатися належним йому майном. Констатовано, що досить часто реалізація таких правовідносин неможлива в результаті прямого кримінально-протиправного впливу на майно (наприклад, його викрадення), чи опосередкованого впливу на майно (наприклад, заволодіння при шахрайстві) як предмет кримінального правопорушення. Проаналізовано спосіб заподіяння майнової шкоди у тих випадках, коли винна особа не виконує своїх зобов'язань, визначених договором або законом. Також проведено розмежування майнової шкоди у вигляді реальних збитків від інших видів шкоди, що може бути заподіяна в результаті вчинення кримінального 
правопорушення. Вказано на найбільш типові методики розрахунку розміру завданої майнової шкоди в грошовому еквіваленті.

Ключові слова: майно, реальні збитки, упущена вигода, майнові втрати, доходи.

Zakharchuk Viktor Mykolayovych Candidate of Law, Associate Professor, Associate Professor of the Department of Criminal Law and Procedure, Leonid Yuzkov Khmelnytsky University of Management and Law, Khmelnytsky, 29000, Heroes of the Maidan St., 8, tel.: (097) 74539 54, e-mail: yur_viddil@univer.km.ua, https://orcid.org/0000-0002-0896-3747

\title{
PROPERTY DAMAGE IN THE SYSTEM OF CRIMINAL AND ILLEGAL CONSEQUENCES
}

\begin{abstract}
The article carries out a scientific study of property damage as one of the types of criminal consequences. The system of criminal offenses is systematized, the obligatory sign of the objective side of which is the consequences in the form of property damage or the threat of such damage. It is established that quite often the presence of property damage in a certain amount determines the recognition of an act as a criminal offense of a certain type or serves to differentiate criminal liability by allocating qualified and especially qualified corpus delicti. In this case, property damage is determined in each case, based on an assessment of all the specific circumstances of the case.

It is investigated that in determining the type and amount of property damage as a criminal offense, first of all it is necessary to use the civil law understanding of this concept. It is established that in the theory of criminal law there are two radically different approaches to the inclusion in the property damage of lost profits, which is not a direct material damage. The mechanism of causing property damage to the object of criminal protection is analyzed. Mostly it consists in the rupture of social relations of possession, use and disposal of the owner of the property belonging to him. It is stated that quite often the implementation of such legal relations is impossible as a result of direct criminal-illegal influence on property (for example, its theft), or indirect influence on property (for example, possession by fraud) as a subject of a criminal offense. The method of causing property damage in those cases when the guilty person does not fulfill its obligations under the contract or law is analyzed. A distinction was also made between property damage in the form of real damages from other types of damage that may be caused as a result of committing a criminal offense. The most typical methods of calculating the amount of property damage in cash are indicated.
\end{abstract}

Keywords: property, real losses, lost profit, property losses, income. 
Постановка проблеми. Крадіжки, грабежі, розбої, вимагання, знищення або пошкодження майна, різного роду шахрайства, ухилення від сплати аліментів, податків та багато інших кримінальних правопорушень завдають майнової шкоди, що полягає в позбавленні власника належних йому цінностей, грошей, іншого майна та матеріальних благ, неотриманні доходів, податків, платежів тощо. Загалом, злочинні посягання, що реально заподіюють майнову шкоду, або такі, у яких така шкода $\epsilon$ різновидом іншого за юридичною формою наслідку, передбачено у досить великій кількості статей Особливої частини Кримінального кодексу України. Зокрема, поняття «значна майнова шкода» як наслідок вчинення особою кримінального правопорушення є у диспозиціях чотирьох статей (ч. 3 ст. 110-2, ч. 1 ст. 192, ч. 1 ст. 258, ч. 2 ст. 258-5 КК України). Окрім поняття значної майнової шкоди, законодавець як кваліфікуючі чи особливо кваліфікуючі ознаки також використовує поняття «майнова шкода у великих розмірах» (ч. 3 ст. 189, ч. 2 ст. 192 , ч. 3 ст. 265 , ч. 3 ст. 265-1, ч. 1 ст. 270 , ч. 1 ст. 270-1 КК України) та «майнова шкода в особливо великих розмірах» (ч. 4 ст. 189, ч. 2 ст. 194, ч. 2 ст. 270, ч. 3 ст. 270-1 КК України). Але при цьому досить часто поняття «майнова шкода» $\epsilon$ оціночним в залежності від наявності або примітки до статті КК України, в якій законодавець конкретизує розмір заподіяної шкоди, або відповідних визначень щодо заподіяної майнової шкоди, які містяться в інших нормативно-правових актах чи відповідних судових роз'ясненнях. У більшості складів кримінальних правопорушень, об'єктивна сторона яких характеризується наслідками у виді заподіяння майнової шкоди, така шкода обраховується шляхом вказівки на неоподатковуваний мінімум доходів громадян. Також в багатьох випадках поняття «майнова шкода» у диспозиції статті не згадується, але однозначно випливає з іiі розуміння. Зокрема, це може бути в окремих випадках, коли для опису суспільно небезпечних наслідків кримінального правопорушення використовується поняття «інші тяжкі наслідки» (наприклад статті 194-1, 206 КК України). В нормах Загальної частини КК України майнова шкода враховується при кваліфікації обставин, що виключають кримінальну протиправність діяння, при визначенні можливості звільнення особи від кримінальної відповідальності, при призначенні покарання, при встановленні розміру штрафу, що має бути призначений за вчинення кримінального правопорушення тощо.

Зміст цього наскрізного кримінально-правового поняття, його сутність, структура, різновиди та значення й досі викликають серйозні проблеми як на законодавчому рівні, так i на рівні теорії кримінального права та судової практики. Зокрема, аналіз практики застосування кримінального закону свідчить, що необхідне уточнення розміру шкоди, що лежить в основі розмежування злочинних i незлочинних діянь, а також при розмежуванні кваліфікуючих обставин. Певної уніфікації потребують способи опису майнової шкоди. Також 
самостійну кримінально-правову проблему утворює оцінка суспільно небезпечних наслідків, пов'язаних з упущеною вигодою для потерпілого.

Аналіз останніх досліджень і публікацій. Вагомий внесок у розроблення досліджуваної проблематики внесли такі вчені як П.С. Берзін, В.І. Борисов, Л.П. Брич, Л.М. Демидова, Р.І. Лемеха, Р.Л. Максимович, .І. Митрованов, А.А. Музика, В.О. Навроцький, С.І. Остапенко, Є.Л. Стрельцов, А.В. СеменюкПрибатень, В.Б. Харченко, С.С. Яценко та інші правознавці.

Метою статті $\epsilon$ проведення аналізу кримінально-протиправних наслідків у виді майнової шкоди як наскрізного кримінально-правового поняття та явища реальної дійсності, а також осмислення теоретичних і практичних проблем, пов’язаних $з$ визначенням майнової шкоди.

Виклад основного матеріалу. Поняття «майнова шкода» в юридичній науці розуміється як будь-яке знецінення особистого чи майнового блага, що охороняється правом, як сукупність несприятливих для особи, якій вона завдана, особистих майнових наслідків [1, с. 729]. П.С. Берзін вказує, що поняття майнової шкоди позначає негативні зміни в об'єкті кримінально-правової охорони, що впливають на майновий стан потерпілого. На його думку, поняття майнової шкоди є показником суспільної небезпечності вчиненого винним злочину певного виду чи його окремого різновиду [2, с. 8].

Майнова шкода досить часто виконує функцію диференціації кримінальної відповідальності, якщо їі різновиди передбачені законодавцем як ознака простого, кваліфікованого чи особливо кваліфікованого складу кримінального правопорушення. Однак фундаментальне значення майнової шкоди як кримінально-правового поняття полягає в тому, що вона $є$ видом суспільно небезпечного наслідку. Тому залежно від конструкції статей кримінального закону вона може бути обов'язковою ознакою об’єктивної сторони кримінального правопорушення з матеріальним складом.

Зважаючи на те, що поняття «майнова шкода», як і поняття «майно» $\epsilon$ поняттями цивільного права, тому кримінально-правове тлумачення майнової шкоди слід першочергово співвідносити з цивільно-правовим розумінням даного терміну.

У сфері цивільного права майном як особливим об'єктом вважаються окрема річ, сукупність речей, а також майнові права та обов’язки (ст. 190 Цивільного кодексу України). Традиційно до майна відносять речі, грошові кошти, цінні папери. Майно може бути рухоме i нерухоме. До рухомого майна належать валютні цінності, грошові кошти, засоби виробництва, культурні цінності, вироблена продукція, транспортні засоби тощо. Нерухомим майном є земельні ділянки, будівлі, споруди та об’єкти електроенергетики. Нерухоме майно не може бути предметом викрадення, тобто кримінальних правопорушень, передбачених 
статтями 185-187 КК України. Однак воно може виступати предметом кримінальних правопорушень, передбачених статтями 189-191, 194-197-1 КК України.

Відповідно до ч. ст. 22 ЦК України є два види майнової шкоди:

1) втрати, яких особа зазнала у зв'язку зі знищенням або пошкодженням речі, а також витрати, які особа зробила або мусить зробити для відновлення свого порушеного права (реальні збитки);

2) доходи, які особа могла б реально одержати за звичайних обставин, якби їі право не було порушене (упущена вигода) [3].

При визначенні поняття «збитки» доцільно використовувати формулу, запропоновану ще римськими цивілістами, відповідно до якої майновою шкодою (збитками) вважалося обчислене в грошах будь-яке зменшення наявного майна та інше ущемлення майнового інтересу однієї особи, заподіяне протиправними діями іншої особи, яке складається з втрат наявного та втраченої вигоди [4, с. 46].

Реальні збитки традиційно поділяють на прямі - вони полягають у вартості майна, що було втрачене власником в результаті вчиненого кримінального правопорушення (наприклад - вартість викрадених ювелірних прикрас, транспортного засобу тощо) та побічні збитки - додаткові витрати, які понесла постраждала сторона [5, с. 336]. Наприклад, при умисному знищенні чужого майна шляхом підпалу прямі збитки - це втрати, що пов'язані зі знищенням або пошкодженням майна вогнем, водою при гасінні. А побічні збитки - це оцінені у грошовому вираженні витрати на гасіння пожежі та ліквідацію іiі наслідків, у тому числі на відбудову об'єкта, що був знищений чи пошкоджений.

Майнова шкода у вигляді реальних збитків відрізняється від інших видів шкоди (в першу чергу фізичної та моральної) тим, що ії можна точно визначити у грошовому еквіваленті. Водночас майнова шкода може виникати не тільки в результаті посягання на майно, а й при посяганні на особу [6, с. 24]. Зокрема, коли було вчинене злочинне посягання на здоров'я особи, в результаті чого постраждалий втрачає заробіток у зв'язку 3 хворобою, здійснює витрати на лікування тощо.

Реальні збитки мають подвійну правову природу - економічну і юридичну. Економічна полягає у тому, що збитки - це негативні наслідки у формі зменшення майнових благ. Юридична природа збитків полягає у порушенні певних правовідносин власності. При цьому постраждала особа має право вимагати від винної особи відшкодування таких збитків.

На відміну від реальних збитків, фактичну вартість яких можна виявити на основі оцінки прямих майнових втрат, завданих особі, втрачена вигода полягає у неотриманих доходах.

Дохід є поняттям економічним. Як економічна категорія дохід позначає 
збільшення активів і зменшення зобов'язань певної особи, що призводить до збільшення власного капіталу. У валовий дохід включають виручку, грошові надходження від продажу товарів і послуг, виконання робіт, продажу майнових цінностей, відсотки, одержані за рахунок надання грошей у кредит, інші грошові та матеріальні надходження. Відповідно до ст. 142 Господарського кодексу України прибуток (дохід) суб’єкта господарювання $є$ показником фінансових результатів його господарської діяльності, який визначається шляхом зменшення суми валового доходу суб'єкта господарювання за певний період на суму валових витрат і суму амортизаційних відрахувань [7].

Майнова шкода від кримінального правопорушення також може бути комбінованою - у вигляді прямих втрат i неотримання належного доходу (наприклад винна особа шахрайським шляхом вилучила у потерпілого земельну ділянку, в результаті чого була припинена сільськогосподарська підприємницька діяльність останнього).

Однак у теорії кримінального права триває дискусія довкола питання щодо того, чи може майнова шкода полягати у втраченій вигоді? 3 цього питання існує два підходи. Відповідно до першого існує можливість включення до обсягу матеріальної шкоди не лише прямих матеріальних збитків, а й неотриманих доходів. Автори другого підходу не визнають втрачену вигоду істотною шкодою $[8$, c. 245$]$.

В абз. 4 п. 6 постанови Пленуму Верховного Суду України від 26 грудня 2003 p. № 15 «Про судову практику у справах про перевищення влади або службових повноважень» пояснюється, що «при вирішенні питання про те, чи є заподіяна шкода істотною, слід також урахувати розмір упущеної вигоди» [9]. Отже це означає, що в окремих випадках заподіяна кримінальним правопорушенням майнова шкода встановлюється 3 урахуванням не тільки реальних втрат потерпілого, а й упущеної вигоди (недоодержання належного).

Загалом видається, що друга позиція все ж є більш виправданою, оскільки втрачена вигода не $є$ прямою шкодою. Окрім того, на момент вчинення кримінального правопорушення відповідний дохід, який особа повинна була в майбутньому одержати, ще не перебував у ii фактичному володінні. Тому неодержані доходи, за умови реальності їх одержання, повинні визнаватись предметом цивільного позову. При цьому загальна сума стягнення за цивільним позовом може бути більшою (якщо окрім вартості викраденого майна, відшкодуванню також підлягають витрати на відновлення пошкодженого майна) або меншою (якщо частина викраденого майна була повернена винною особою) за розмір завданих збитків [4, с. 47].

Однак в окремих складах кримінальних правопорушень майнова шкода все ж може виступати й у формі упущеної вигоди, зважаючи на конструкції їх 
об’єктивної сторони (наприклад, кримінальні правопорушення $\quad$ у сфері інтелектуальної власності - ст.ст. 176, 177 КК України).

Також видається, що упущена вигода може стати результатом невиконання своїх обов’язків одним із суб'єктів майнових правовідносин. Механізм заподіяння шкоди правоохоронюваному об’єкту тут зводиться до того, що один із учасників суспільних відносин, будучи наділеним обов'язком виконувати певні дії майнового характеру на користь іншого учасника цих же відносин, не виконує такі обов'язки. При цьому наслідки, які настали, за своїм характером відносяться до майнових. Особливість цього виду майнової шкоди полягає в тому, що винний нічого не вилучає у потерпілого, його майно не збільшується, але він неправомірно залишає собі те, що він повинен був передати потерпілій особі відповідно до обов'язків, покладених на нього законом. Класичним прикладом такої шкоди є суспільно небезпечні наслідки, що настають в результаті ухилення від сплати аліментів на утримання дітей (ст. 164 КК України), від сплати податків (ст. 212 КК України).

Також слід звернути увагу на статті, обов'язковою ознакою об'єктивної сторони яких $є$ не майнова шкода у вигляді реальних збитків або упущеної вигоди, а лише загроза заподіяння майнової шкоди - ч. 1 ст. 258 КК України (загроза заподіяння значної майнової шкоди), ч. 1 ст. 265-1 КК України (загроза заподіяння майнової шкоди у великому розмірі). У даних складах кримінальних правопорушень суспільна небезпечність полягає у самій лише погрозі заподіяння майнової шкоди.

Діють різні методики розрахунку розміру заподіяної майнової шкоди в грошовому еквіваленті з врахуванням вартості майна. Найчастіше вартість майна визначається за роздрібними (закупівельними) цінами, що існували на момент вчинення кримінального правопорушення, а розмір відшкодування завданих збитків - за відповідними цінами на час вирішення справи в суді. За відсутності зазначених цін на майно його вартість може бути визначено шляхом проведення відповідної експертизи [10].

Однак в окремих статтях взагалі не визначені жодні критерії визначення розміру заподіяної шкоди (наприклад, ст.ст. 347, 352, 378, 399, 411-413 КК України) Тому для кваліфікації відповідних кримінальних правопорушень сума заподіяної шкоди не має важливого значення.

Висновки. Майнова шкода - це наслідки кримінального правопорушення, що мають грошову форму та полягають у безпосередньому обмеженні матеріального блага особи, у позбавленні іiі можливості одержати заплановані доходи, а також у понесенні особою будь-яких додаткових майнових витрат.

Майнова шкода $є$ одним із видів матеріальної шкоди, однак змістовне наповнення цих понять різне, тому що поняття «матеріальна шкода»є значно 
ширшим, ніж майнова шкода і включає також фізичну шкоду.

У багатьох кримінальних правопорушеннях майнова шкода власнику майна заподіюється шляхом безпосереднього впливу на майно, зокрема шляхом його протиправного вилучення у власника, в результаті чого він втрачає можливість нам володіти і користуватись, та очевидно і розпоряджатись. При цьому фізично майно може не зазнавати жодних змін чи пошкоджень (наприклад, викрадені грошові кошти або транспортні засоби злочинцем не знищуються $i$ не пошкоджуються). Способи заподіяння майнової шкоди можуть полягати у виключенні (вилучення, знищення) певних предметів із сфери суспільних відносин; їх пошкодженні тощо. Додатково також слід виділяти загрозу заподіяння майнової шкоди в результаті знищення чи пошкодження майна.

Характер і розмір майнової шкоди в першу чергу залежить від об'єкта кримінального правопорушення та предмета, відносно якого вчиняється діяння. Розмір майнової шкоди досить часто впливає на диференціацію кримінальної відповідальності, впливає на кваліфікацію кримінального правопорушення та на диференціацію покарання. Крім того, визначення майнової шкоди має важливе правове значення для відновлення порушених прав потерпілого.

Для оптимізації використання поняття «майнова шкода» у різних термінологічних позначеннях його доцільно використовувати лише у тих складах кримінальних правопорушень, де наслідки носять виключно майновий характер i їx можна чітко встановити. У тих же випадках, коли наслідки кримінального правопорушення можуть бути комбінованими (шкода майнового (матеріального) $\mathrm{i}$ нематеріального характеру) доцільно використовувати поняття «істотна шкода».

\section{Jimepamypa:}

1. Цивільне право: підручник. У 2 томах / за ред. В.І. Борисової, I.В. Спасибо-Фатєєвої, В.Л. Яроцького. Х.: Право. 2011. Т. 2. 816 с.

2. Берзін П.С. Деякі особливості визначення розміру покарання у виді штрафу за новою редакцією ст. 53 Кримінального кодексу України. Право і громадянське суспільство. 2012. № 1. C. 8-17. URL: http://papers.univ.kiev.ua/1/jurydychni_nauky/articles/berzin-p-some-features-of-sizepenalties-as-fine-the-new-version-of-art-53-cri_19520.pdf

3. Цивільний кодекс України від 16 січня 2003 року № 435-IV. URL: http://zakon3.rada.gov.ua/laws/show/435-15

4. Митрофанов I.I. «Шкода» та «збитки»: співвідношення понять. Вісник КрНУ імені Михайла Остроградського. 2012. Вип. 3(74). С. 45-51. URL: http://www.kdu.edu. ua/statti/2012-31(74)/196.pdf.

5. Максимович Р.Л. Істотна шкода як наскрізне кримінально-правове поняття. Науковий вісник Львівського державного університету внутрішніх справ. 2013. № 3. С. 335-342.

6. Розізнана I.В. Поняття та ознаки упущеної вигоди в цивільному праві. Юридичний науковий електронний журнал. 2014. № 2. С. 23-27. URL: http://lsej.org.ua/2_2014/8.pdf

7. Господарський кодекс України від 16 січня 2013 року № 435-IV. URL: http://zakon3.rada.gov.ua/laws/show/436-15 
8. Крайник Г. Щодо змісту понять «загибель людей» та «інші тяжкі наслідки» як обтяжуючих обставин, зазначених у ч. 2 ст. 272 КК України. Вісник Академії адвокатури. 2011. № 2 (65). С. 241-249.

9. Про судову практику у справах про перевищення влади або службових повноважень: постанова Пленуму Верховного Суду України № 15 від 26.12.2003 p. URL: http://zakon2.rada.gov.ua/laws/show/v0015700-03.

10. Про судову практику у справах про злочини проти власності: постанова Пленуму Верховного Суду України від 06 листопада 2009 року № 10. URL: http:// zakon1.rada.gov.ua/cgibin/laws/main.cgi?nreg= v0010700-09.

\section{References:}

1. Borysova V.I., Spasybo-Fatyeyeva I.V., Yarotsкa V.L. (2011). Tsyvilne pravo [Civil law]. KH.: Pravo. [in Ukrainian].

2. Berzin P.S. (2011). Deyaki osoblyvosti vyznachennya rozmiru pokarannya u vydi shtrafu za novoyu redaktsiyeyu st. 53 Kryminalnoho kodeksu Ukrayiny [Some features of determining the amount of punishment in the form of a fine under the new version of Art. 53 of the Criminal Code of Ukraine]. Pravo $i$ hromadyanske suspilstvo - Law and civil society, 1, 8-17. URL: http://papers.univ.kiev.ua/1/jurydychni_nauky/articles/berzin-p-some-features-of-size-penalties-asfine-the-new-version-of-art-53-cri_19520.pdf [in Ukrainian].

3. Tsyvilnyy kodeks Ukrayiny [Civil Code of Ukraine, from January 16, 2003, № 435-IV]. (n.d.). zakon.rada.gov.ua. URL: http://zakon3.rada.gov.ua/laws/show/435-15 [in Ukrainian].

4. Mytrofanov I.I. (2012). «Shkoda» ta «zbytky»: spivvidnoshennya ponyat [«Damage» and «losses»: the relationship of concepts]. Visnyk KrNU imeni Mykhayla Ostrohrads'koho - Bulletin of Mykhailo Ostrogradskyi KrNU, 3 (74). 45-51. URL: http://www.kdu.edu. ua/statti/2012-31(74)/196.pdf. [in Ukrainian].

5. Maksymovych R.L. (2013). Istotna shkoda yak naskrizne kryminalno-pravove ponyattya [Significant damage as a pervasive criminal law concept]. Naukovyy visnyk Lvivskoho derzhavnoho universytetu vnutrishnikh sprav - Scientific Bulletin of Lviv State University of Internal Affairs, 3, 335342. [in Ukrainian].

6. Roziznana I.V. (2014). Ponyattya ta oznaky upushchenoyi vyhody v tsyvilnomu pravi [The concept and signs of lost profits in civil law]. Yurydychnyy naukovyy elektronnyy zhurnal - Legal scientific electronic journal, 2. 23-27. URL: http://lsej.org.ua/2_2014/8.pdf [in Ukrainian].

7. Hospodarskyy kodeks Ukrayiny [Commercial Code of Ukraine from January 16, 2013, № 435-IV] (n.d.). zakon.rada.gov.ua. URL: http://zakon3.rada.gov.ua/laws/show/436-15 [in Ukrainian].

8. Kraynyk H. (2011). Shchodo zmistu ponyat «zahybel lyudey» ta «inshi tyazhki naslidky» yak obtyazhuyuchykh obstavyn, zaznachenykh u ch. 2 st. 272 KK Ukrayiny [Regarding the content of the concepts of «death» and «other serious consequences 2 as aggravating circumstances specified in Part 2 of Art. 272 of the Criminal Code of Ukraine]. Visnyk Akademiyi advokatury - Bulletin of the Bar Academy, 2 (65), 241-249. [in Ukrainian].

9. Postanova Plenumu Verkhovnoho Sudu Ukrayiny «Pro sudovu praktyku u spravakh pro perevyshchennya vlady abo sluzhbovykh povnovazhen» [Resolution of the Plenum of the Supreme Court of Ukrain «On Judicial Practice in Cases of Excess of Power or Official Powers» from November. 6, 2003 № 15]. (n.d.). zakon.rada.gov.ua.. - URL: http://zakon2.rada.gov.ua/laws/show/ v0015700-03. [in Ukrainian]. 
10. Postanova Plenumu Verkhovnoho Sudu Ukrayiny «Pro sudovu praktyku u spravakh pro zlochyny proty vlasnosti. [Resolution of the Plenum of the Supreme Court of Ukraine «On Judicial Practice in Cases of Crimes Against Propert» from December, 26, 2009. № 10]. (n.d.). zakon.rada.gov.ua. URL: http:// zakon1.rada.gov.ua/cgibin/laws/main.cgi?nreg= v0010700-09. [in Ukrainian]. 